\title{
THE DESIGN OF MOSQUES AS COMMUNITY DEVELOPMENT CENTERS FROM THE PERSPECTIVE OF THE SUNNA AND WRIGHT'S ORGANIC ARCHITECTURE
}

\author{
Mohamad Tajuddin Mohamad Rasdi \\ Department of Architecture, Faculty of Built Environment, \\ Universiti Teknologi Malaysia, Johor Bahru, Malaysia \\ e-mail:mindakritis@yahoo.com
}

Nangkula Utaberta

Department of Architecture, Faculty of Engineering and Built Environment, Universiti Kebangsaan Malaysia, Kuala Lumpur, Malaysia

e-mail:nangkula_arch@yahoo.com

\begin{abstract}
The main purpose of this paper is to present an alternative approach to mosque design with particular reference to the context of Malaysia and the Malay World or the Nusantara. The paper contains four main parts. The first part examines the problem of mosque architectural interpretation from the perspective of Western architectural historiography. The main problems highlighted are those which pertain to the idea of 'architecture', 'religious architecture', relevance of the body of knowledge known as the 'Hadith' and lastly the specific historical-political agenda of some traditional mosques. The second part of the paper expounds briefly a reinterpretation of the hadith in arguing that the mosque approaches more as a community development complex than that as a mere house of rituals. The third part of the paper examines Wright's Organic Architecture with specific reference to the design of the Unity Church and a few other buildings as containing some important lessons of mosque designs from the perspective of the Sunnah. The final part of the paper uses the principles discussed to criticize the Putra Mosque and the Masjid Negara.
\end{abstract}

Keywords: Sunna, Organic Architecture, mosque design, Frank Lloyd Wright

\begin{abstract}
Abstrak
Kajian ini berupaya untuk menghadirkan pendekatan alternatif terhadap perancangan masjid dengan referensi kontekstual dari Malaysia atau Nusantara. Bagian pertama dari kajian ini memaparkan mengenai permasalahanpermasalahan interpretasi arsitektural masjid dari perspektif historiografi arsitektural Barat. Permasalahan utama yang dititikberatkan pada kajian ini melingkupi ide mengenai 'arsitektur', 'arsitektur religius', relevansi Hadits sebagai salah satu referensi batang tubuh pengetahuan arsitektur Islam, dan agenda-agenda historispolitis dari beberapa masjid tradisional. Lebih jauh, kajian ini juga memaparkan mengenai reinterpretasi hadits mengenai fungsi masjid sebagai pusat pengembangan masyarakat, di luar fungsinya yang selama ini hanya dikenal sebatas sebagai tempat menjalankan ibadah shalat berjamaah. Selanjutnya, kajian ini ditujukan pula untuk menjadikan ide Arsitektur Organik Wright dalam desain Unity Church dan beberapa bangunan lainnya sebagai beberapa contoh penting bagi perancangan masjid dari perspektif Sunnah. Pada bagian akhir, kajian ini akan ditutup dengan paparan mengenai penggunaan beberapa prinsip Arsitektur Organik tersebut untuk mengkritisi desain arsitektural Masjid Putra dan Masjid Negara.
\end{abstract}

Kata kunci: Sunnah, perancangan masjid, Frank Lloyd Wright, Arsitektur Organik

\section{Introduction: The Idea of the Mosque from the Hadith}

Al-Hadith contains many references to the use and functions of the mosque during the Prophet's time. The Prophet had also mentioned a few admonishment concerning the building of mosques. Concerning the functions of mosques, the hadiths contain many accounts of the uses of Masjid alHaram in Mecca and the Prophet's own mosque in Medina. There are many references about the social conditions of the area surrounding the Ka'ba. The mosque was used as a gathering place for all the nobles of the Arab society. The traditions record political pronouncements and diplomatic exchanges taking place at close proximity to the Ka'ba. The Prophet had engaged in many debates, discussions and preaching at the Holy Mosque. All of these seem to indicate that the idea of sanctity in religious structures is not one in which only a particular ritual is intended. Of course, some historians might argue that the Arabs were not civilized enough to know the difference between a town hall and a religious building. The historian might even go as far as suggesting the Arabs were too poor to have separate edifices for the secular and religious functions. This manner of argument has the flaw of stereotyping every society into neat little packages of entities Journal of Islamic Architecture Volume 1 Issue 1 June 2010 | 1 
that must follow a universal religious and political law.

The Prophet's Mosque in Medina was also used in the same manner as a social, political and religious center. There are hadiths which includes the functions of a shelter, an educational institution, a health care facility and a prison. Celebrations and recreational activities were also held near the mosque. The mosque was also a grim stage to pass judicial decisions and the implementation of punishment in the form of stoning. Finally, the Prophet had also admonished the Muslims in being wasteful about constructing monumental mosques and buildings as in the following hadiths:

"I was not commanded to build high mosques."1

"One of the portents of the Day of Judgment is that you will vie with one another in building mosques."

The reference to the term 'high' mosque need not necessarily be interpreted literally since it obviously connotes a sense of wastage in construction. The Prophet's life is an example of moderation.

Thus, from the hadith we can understand that the idea of the mosque does not approach that of a monumental building meant for a single ritual worship act. The mosque it seems was a place where the Muslims gather to interact and discharge many responsibilities for the benefit of Islam. We will show that all their activities, most of it considered secular by the historians, fall into the category of 'worship' or ibadat. Thus, the mosque as a house of worship has a different connotation in Islam than in other religions.

\section{The Meaning of Worship and the Eternal Idea of the Mosque}

The idea of worship in the normal usage of the English language usually connote an act specifically set in the religious and ritualistic context. In Islam the word worship is the only closest word which is used to translate the concept of ibadat. Abul A'la Maudidi and Abu Urwah explains that since the word 'ibadat' is a derivative of the term abd or 'slave' the true Muslim is a compliant slave to Allah The Most High. The true Muslim would do Allah's every bidding and in doing so pleases Him:

"It is not righteousness that ye turn your faces to the East or the West, but it is righteousness to believe in God and the Last Day and the Angels, and the Book, and the Messengers; to spend of your substance out of love for Him, for your kin, for orphans, for the needy, for the wayfarer, for those who ask, and for the ransom of slaves; to be steadfast in prayer, and practice regular charity, to fulfill the contracts which ye have made; and to be firm and patient, in pain or suffering and adversity and throughout all periods of panic; such are the people of truth, the God-fearing. "'
Aside from prayers, the Muslim has many social obligations to fulfill. Fulfilling these social responsibilities will help create a conducive religious environment to be at peace with oneself and in the constant remembrance of God. The true Muslim is not one that secludes oneself from the society as in the following hadith:

"Narrated Ab, Sa'id Al-Khudri: Somebody asked, "O Allah's Apostle! Who is the best among the people?" Allah's Apostle replied, "A believer who strives his utmost in Allah's Cause with his life and property." They asked, "Who is next?" He replied, "A believer who stays in one of the mountain paths worshipping Allah and leaving the people secure from his mischief. ${ }^{.4}$

Thus, if we understand this definition of worship, can we not see a different picture of the Prophet's mosque's role and functions during his life time? We must agree that the idea of the mosque approach not as a building for a single set of ritual worship but more of a kind of social center.

\section{A Brief Overview of Mosque Architecture in Malaysia}

Since the day Islam set onto Malaysia's soil over seven centuries ago, there have been many kinds of architectural language used in mosque designs. The earliest typology of mosques in this country is believed to be those built purely of timber with the characteristic pyramidal roof of two or three tiers and also those of the long gable house-type. The Kampung Laut (around 300 years old) and Kampung Tuan Mosques are two typical examples of the earliest type of three tiered pyramidal room form with raised floor and an obvious absence of minaret.

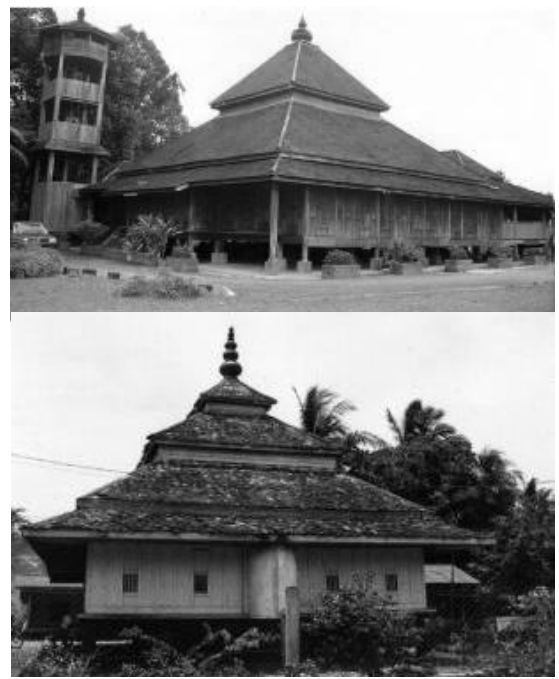

Figure 1. The Kampung Laut (above) and Kampung Tuan Mosque (below)

These mosques (Figure 1) are characteristically square in plan and seemed to be proportioned after the dimensions of a cube. The Masjid Langgar shows the common house-type long gable roof form. When 
masonry construction was introduced, there was a proliferation of a second generation pyramidal three tiered roof form but this time with solid masonry walls and floors on grade. The Tengkera Mosque (Figure 2) represent this typology with its characteristic pagoda-like tiered roofs and curved roof ridges. Up to this time the scale of the mosque would fit a community of about five hundred Muslims in villages. The mosques from both generation can claim a totally regionalistic approach of response to climate in its tiered roof for ventilations, raised floors and also the presence of the serambi. The minaret began to make itself felt in the masonry mosque period.

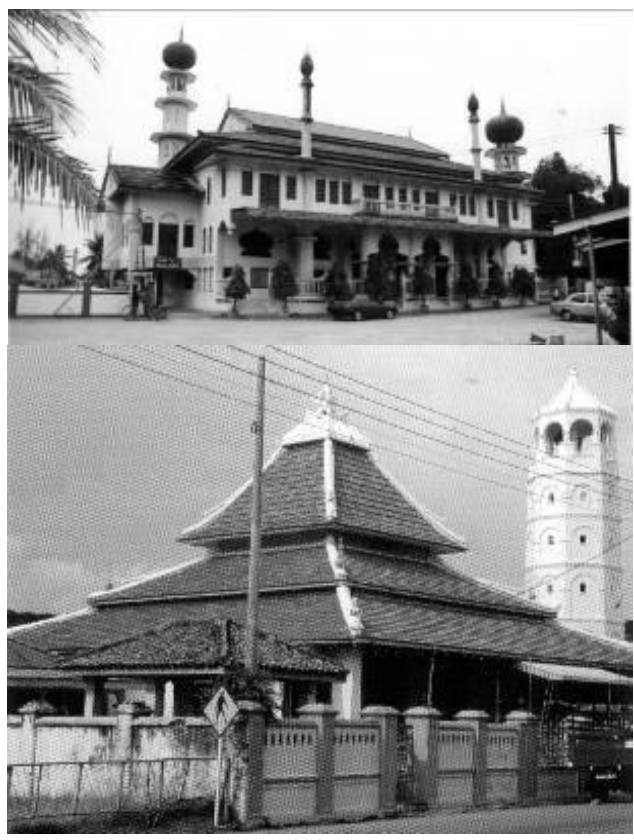

Figure 2. The Langgar (above) and Tengkera Mosque (below)

The British who colonised Malaysia for about two centuries brought in the exotic languages of Moghul and Moorish mosque architectural vocabulary. The Jamek Mosque in Kuala Lumpur represents an eclectic approach of both languages with onion domes, multiple towers and finials complete with horseshoe arches reminiscent of the Muslim-Cordoban architecture. The British also introduced the Western Classical syntax as in the Abu Bakar Mosque in Johor (Figure 3). The era of the grand, monumental and isolated mosque actually began with the British. Before this, the mosques have always been surrounded by village huts and directly accessible to the worshippers. With the increased in density of settlements, a simplistic solution of bigger mosques-more worshippers formula seem to be the order of the day. There was no questioning the role and main purpose of the mosque as a community development center but merely as the symbol of the glory of Islam. The modern international wave swept over Malaysia and brought with it the structuralist and machine aesthetic of mosque designs as can be seen in the Negeri Sembilan State Mosque (Figure 4) and also that of Penang. Post Modern architecture then opened a Pandora box of Egyptian, Iranian and Turkish eclectic revivalism. The Wilayah Mosque, the Putra Mosque are recent epitomes of the grand monumental and over priced structures which the government uses to suggest their symbolic commitment to Islam. More Middle Eastern and Turkish mosques are expected to be making their debut in the short future.

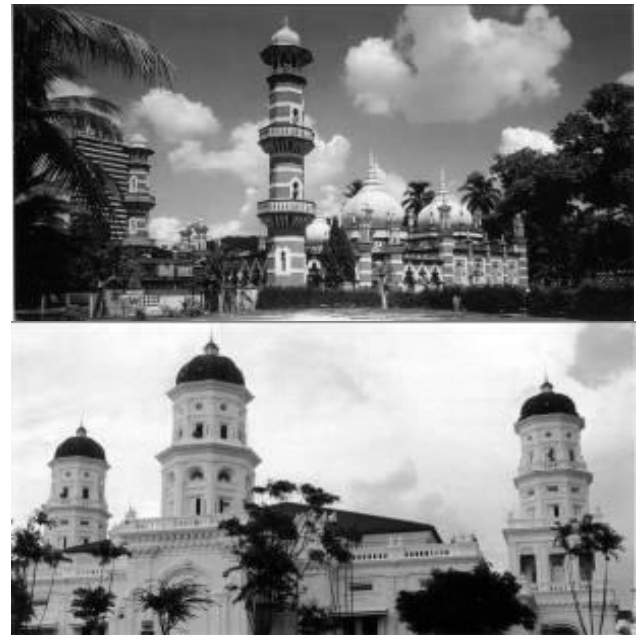

Figure 3. The Jamek and Abu Bakar Mosque

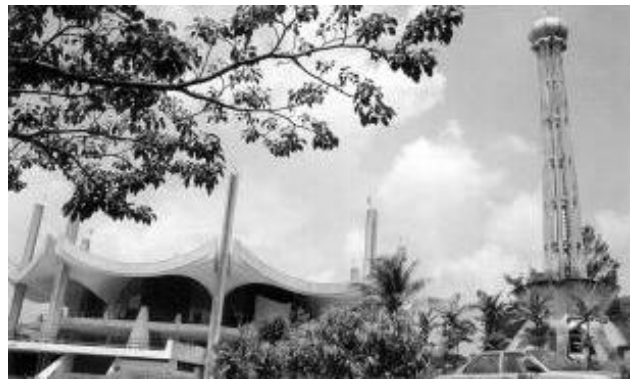

Figure 4. Negeri Sembilan State Mosque

\section{Wright's Principle of Organic Architecture: A Lesson for Mosque Architecture}

Wright would have liked to be known as a 'Student of Nature'. The way he glorifies Nature in the sense of learning from it, humbling his architecture to it and constantly reminding people of Nature's presence in his use of natural materials and his planning organization of buildings, one would be forced to think that Nature was Wright's true religion. Though he was a Christian but his preference for the Unitarian principles comes close to Islam's tauhidic approach towards the creation. In this section, we will examine four of his works in order to draw some strong ideas towards rethinking 
the priorities of mosque architecture per se and to Islamic Architecture as a whole.

We will first of all examine Wright's Unitarian Church. There are many important design principles inherent in this work that can offer lessons to mosque architecture. First of all let us consider the scale of the building. In an era where huge mosques that can house hundreds of thousands at one time, it is humbling to find a church with a small community scale. Mohd. Tajuddin in his two books have been arguing for smaller mosques that would encourage the qari'ah to strengthen their Islamic brotherhood. ${ }^{5}$ Monumental architectural works that are so prevalent in today's mosque also has the characteristics of arrogance in its huge size and expansive setback distances. The Unitarian Church is lower than the trees that surrounds it making a clear statement as to which is more important; man's creation or God's? Mosque designers should try to break up the scale of their works and ensure the dominance of trees over the main building (except the minaret) be obvious so as to encourage contemplation of God's creation. In Surah Ar' Rad Allah the Most High commands man to contemplate His Creations:

"And it is He Who spread out the earth, and set thereon mountains standing firm, and rivers and fruit of every kind He made in pairs, two and two. He draweth the night as a veil over the day. Behold, verily in these things there are Signs for those who consider. And in the earth are tracts neighbouring, and gardens of vines and fields sown with corn, and palm trees, growing out of single roots or otherwise: watered with the same water, yet some of them We make more excellent than others to eat. Behold, verily in these things there are Signs for those who understand!"

We will next look at the use of materials. For mosques designs in the present day, highly polished marble and tiles seem to be the order of the day. Wright prefer to use natural materials such as stone and timber. Wright would never think of applying a coat of plaster or even of painting the timber components as he wishes their texture to be discern by all. We find that this aspect of organic principle to be one of the most important lessons in mosque design. The use of natural materials has the power to remind man of its primeval origins. Stone and timber were here long before man set foot in this world. This connection to the primitive past helps to bring man down from the high pedestal which he has created for himself in the modern world. With all his modern gadgetry and humbling of nature man has forgotten that he is a mere 'keeper of the world' for Allah until a particular time. The use of natural materials can also help man discharge his duty as the vicegerent of Allah as they are sustainable materials. The materials do not need any maintenance and projects an eternal quality that brings great maturity to its aging process. If man were surrounded by plastered concrete walls and metal curtain partitions he would be surrounding his own 'greatness' and not the greatness of the Creator.

The most characteristic of Wright's architectural works is his preference for the strong horizontal expression of his buildings. In many writings, Wright has referred this horizontality to the horizon line of the open prairie ${ }^{7}$. This horizon line is again another primeval reminder and it also acts as 'weight' to tie the building down to the ground thus creating a secure sense of shelter. Many mosques are design standing vertically upright without a tawadhu sense of humility. The church in question as well as most of Wright's buildings, has a quality of humility that we do not find in many so called 'islamic' works. The non-existence of the idea of humility in Islam is an irony to the meaning of its word as 'submission to the will of Allah'.

Wright was never an advocate of revivalism nor was he ever known to condone eclecticism in any form whatsoever ${ }^{8}$. From his Prairie School period to his 'Cubist' era and finally to his structuralist preference, Wright had always believed in the idea of 'spirit of the times'. The idea of spirit of the times simply postulates that each building truthfully produced in an era reflects the technological prowess and the economic condition of that particular period. Revivalism seek to lie about true conditions and simplistic nostalgic references can never be seriously taken as an important rationale to produce works of socio-political importance.

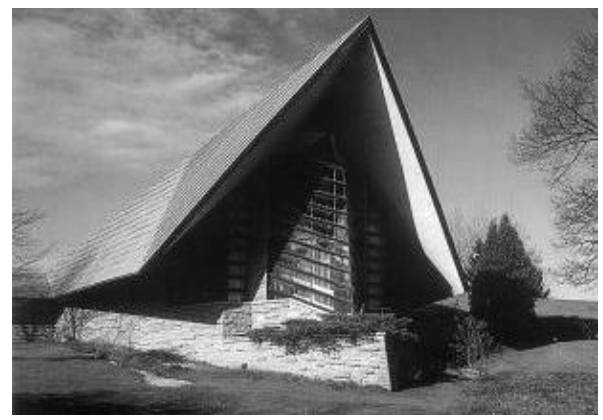

Figure 5. Unitarian Church

Thus Wright rejected the use of typological church models in his designs of both the Unity Temple and the Unitarian Church (Figure 5). He believes that religion is a progressive and not a dogmatic practice. With his rejection of the established typological reference of religious architecture, Wright has liberated the idea of religious practice as a true independent relationship between the individual worshipper and God without any intermediary whatsoever. This is an important lesson for the design of mosques nowadays seem to relish the notion of a sacred vocabulary and syntax in its reference to middle eastern, African and 
Mediterranean domes, arches, minarets, courtyards and ornamentation.

The siting of the church as not overpowering the landscape or striding the hill in a commanding posture leads one to the idea of , again, humility to God's work. There is absolutely no mistaking the presence of a mosque in the contemporary context as clients prefer them up on a hill like a monarch surveying his peasantry. The asymmetrical massing brings about the idea that religion is not a totalitarian production as all are equal under the eyes of God, priest, imams, ministers and generals alike. The idea of monumental symmetry is a production of feudalistic society where both kings and clerics would hold the masses in their iron grips simply because they were the keepers of knowledge and the kitabs. In the present day, everyone has access to the kitab and thus everyone can keep their leadership in check based on a single frame of reference. This is actually the ideal of 'democracy' which relates to the liberalization and distribution of society's power. We, therefore, feel that the church shows better 'Islamic democracy' then any most that are found in Malaysia.

Besides the Unitarian Church, lessons can also be drawn from other Wright's work. The Martin house (Figure 6) offers important lessons in the integration of landscaping elements with the strength of organization of spaces. Instead of lumping all the spaces into a single mass, Wright had separated it into three volumes interconnected by passageways. What he has ingeniously done is to provide a leisurely but ceremonious journeys to all the different spaces in the house by encouraging the dwellers to view the plants and trees littered throughout the gardens in the small courtyards created. As with the quoted verses in Surah ar-Ra'd, the mosque can benefit from such a strategy that would not only encourage the reminder of God but also sooth the spirit and cools the building by solar absorption.

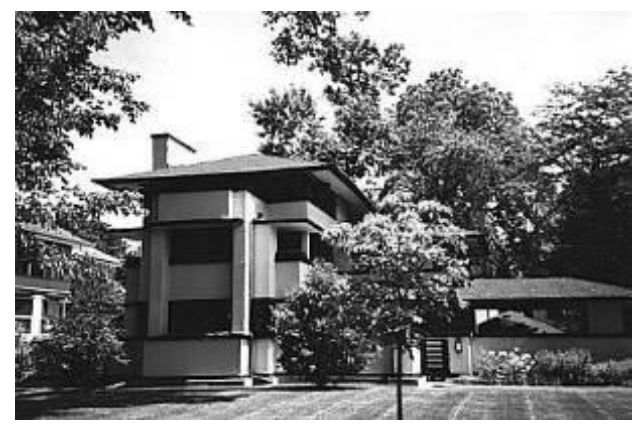

Figure 6. Martin House

Wright is most concerned about sustainable architecture which can be seen in his preference for natural materials and his energy conservation strategies $^{9}$. In the design of the Friedman House
(Figure 7) Wright buries much of the building in the soil for a natural insulation against heat and orients the building to capture the winter sun rays to heat the house. In the tropics such as Malaysia an emphasis to openness and the use of pools of water for cooling and encouragement of convective air currents is desirable. However many mosques disregard this principle and some have even opted for the use of mechanical means of cooling just so that they can use the fortress like images of the middle eastern mosque typologies. Islam encourages actions of conserving resources and abhors wasteful acts of any kind. The Prophet was known to have admonished his followers not to be wasteful in performing ablution even if the water was from an abundantly flowing river.

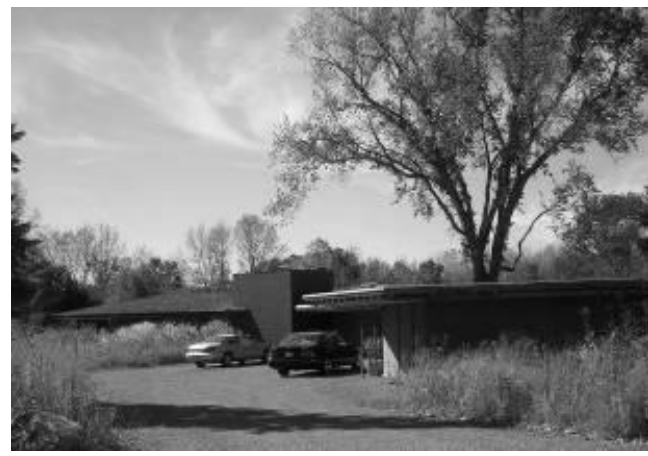

Figure 7. Friedman House

The use of integrated ornamentation is another of Wright's strength in design. This subject is relevant to Islam as everyone is aware of the so called legacy of islamic ornamentation in the form of written scripts or geometric patterns. Wright never advocated the direct revivalism or imitation of traditional ornaments but chooses to select his own motifs and composition of ornamentation. Muslim architect must understand that in this way better meaning can be ensured to the ornaments and can be easily appreciated and understood by local cultures. In the Unity Temple (Figure 8), Wright displays his powers of integrating ornament into the building's exterior characteristics and he had also rendered the interior ornamentation within the De Stijl or cubist perspectives as part of the ceiling moldings, fixtures and wall paneling. In many other designs, Wright integrates the heating coils of houses and furniture as a complete organic entity for the buildings. Thus the interconnectedness of the fixture, furniture, finishing and other ornamental details all add up to a complete unifying tauhidic approach.

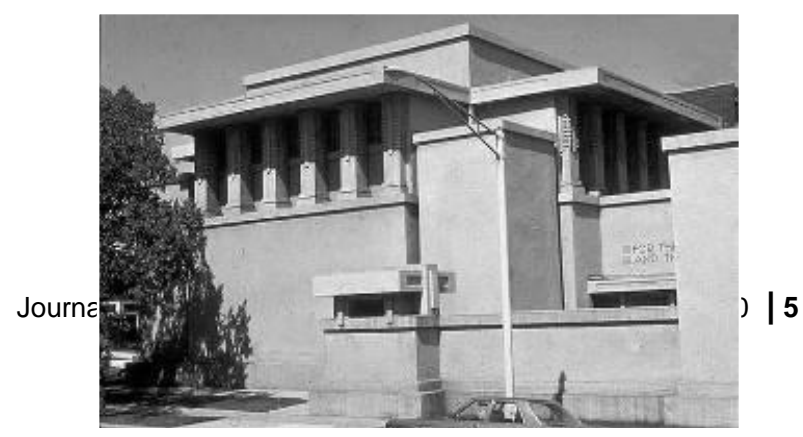




\section{Figure 8. Unity Temple}

We can, therefore, see that Wright has many principles that are directly relevant to the design of mosques not as a monumental and glorified symbol but as a product that disintegrates into the landscape whilst emphasizing the lessons of Nature as the main theme of reminding the Muslim of its humility and humble origins.

\section{A Critic of the Putra Mosque and the Masjid Negara from Wright's Organic Principle}

In this section we present a criticism of the Putra Mosque and Masjid Negara from the perspective of Wright's philosophy. With regard to the use of architectural language, we can obviously see the weakness in the Putra Mosque. Its reliance on the eclecticism and revivalism of a foreign tradition makes a statement as if Malaysian Muslims have an inferiority complex to that of the middle east. Where, in the Qur'an or in the Sunna does the Prophet make reference to the iconoclastic stature of the elements of domes, minarets and arches? The three elements thus mentioned have never existed in the Nusantara typology of timber mosques in this region. The use of domes, and arches are a result of an ancient understanding of masonry construction. The Masjid Negara does not have this problem since it does not have an iota of reference to the traditional middle east and thus can stand proud as a wholly Malaysian product. As to the criticism that the middle eastern language can produce a pan Islamic internationalism we must make the stand that Islam never insisted on a unifying imagery but merely insist on some fundamental ritualistic practices.

With regards to the use of regionalistic response to the climate, Masjid Negara (Figure 9) epitomizes this creed in a wonderful display of serambis or verandahs, air wells, large pools of water for cooling, a generous fenestration area and a depth to height proportion that encourages convective air currents throughout its structure. The Putra Mosque with its small fenestration area, large use of masonry is forced to rely on mechanical means of cooling that wastes energy and resources. The fact that it sits on a man made lake worsens the idea of sustainable architecture in its almost 100 million dollar venture.

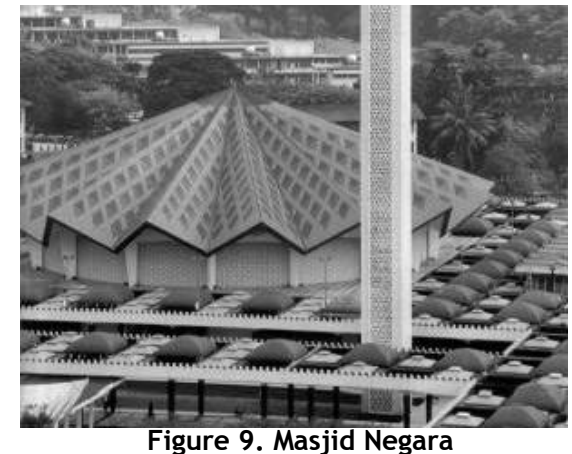

As regard to their massing composition, Masjid Negara settles on an assymetrical approach in contrast to the imperial symetery of the Putra Mosque. Thus Masjid Negara presents an informal invitational gestures to worshippers in contrast to the stiff and regimented tones of the Putra Mosque (Figure 10).

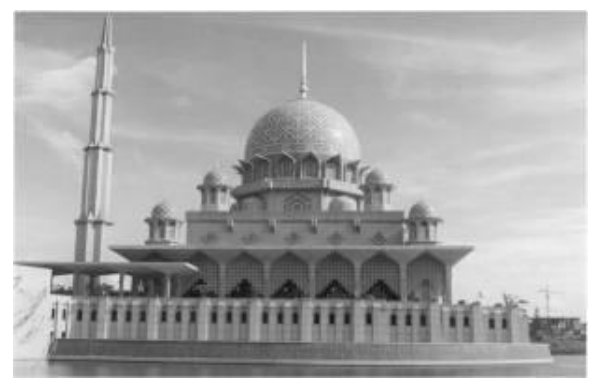

Figure 10. Putra Mosque

The siting of the Putra Mosque leaves much to be desired and someday scholars will write about the effects of pollution on worshippers using vehicular transport to grace the monumental palace like structure. Masjid Negara sits in the midst of Kuala Lumpur near the train station and within walking distance from many public structures. The Putra Mosque is surrounded by a formal gateway with unfriendly fences that presents an irony of an open public structure whereas Masjid Negara sits comfortably without a single fence or gateway that projects a language of friendliness.

The horizontal expression of Masjid Negara presents a humility that is the characteristic of Islam whereas the stark verticality of the Putra Mosque presence an arrogance perhaps befitting the client that commissioned it. Both buildings did not rely on the use of natural materials and thus was unable to project the idea of eternity and primeval origins.

Thus in almost all respects, Masjid Negara presents a regionalistic model that can better present the idea of Islamic architecture in the Nusantara as opposed to the false and wasteful projections of the Putra Mosque. Architects of this reason would do well to learn much lessons from Masjid Negara in not only mosque designs but any 
building that carries the idea of sustainable identity as its main agenda.

\section{Conclusion}

Simplistic revivalism in mosque design can be seen to be interpreted as providing Islam with the attributes of a regressive and uncreative culture, a dogmatic sense of rigidity, an over priced piece of arrogant sculpture and 'white elephant' to be praised but never used efficiently. As designers of mosques we should try to veer away from the cocoon of historicism and attempt to question the fundamental basis of our works. The early modernists such as Wright requestioned almost every facet of what society felt to be truth in architecture and also what they had held deer as the idea of 'life'. It is our time now to forget about the so called glorious 'Sinans' of our civilization and seek the truth from the direct spirit of the Prophet Muhammad's Sunna and derive our agendas within the framework of present socio-economic and regionalistic concerns which are then synthesized using a creative interpretation of traditional and modern architectural vocabulary. As with the idea of jihad such a struggle will always bear honest fruit for the 'struggle' itself is the actual goal.

\section{References}

1. James Robson. 1973. Mishkat al-Masabih. Lahore: $\mathrm{SH}$

2. Ibid

3. Abdullah Yusuf Ali. 1983. The Holy Qur'an: Translation and Commentary. Surah 2: 177. Maryland: Amana Corporation

4. Muhammad Muhsin Khan. 1966. The Translation of the Meanings on Shahih Al-Bukhari. Beirut: Dar Al-Arabia

5. Mohamad Tajuddin Mohamad Rasdi. 1988. The Mosque as a Community Development Center. Johor: Universiti Teknologi Malaysia

6. Abdullah Yusuf Ali. 1983. The Holy Qur'an: Translation and Commentary. Surah 13: 3-4. Maryland: Amana Corporation

7. Olgivanna Lloyd Wright. 1966. Frank Lloyd Wright; His Life, His Work, His Words. London: Pitman Publishing

8. Frank Lloyd Wright. 1957. Truth Against the World. New York: A Wiley-interscience Publication

9. Frank Lloyd Wright. 1954. The Natural House. New York: Horizon Press 